\title{
The Relationship between Demographic towards the Achievement of a Successful Muslim Entrepreneur in Malaysia
}

\author{
Yazilmiwati Yaacob \\ MOHE-General Studies Department, Sunway University, Bandar Sunway, Petaling Jaya, Selangor, Malaysia \\ Email: yazilmiwati08@gmail.com \\ Ilhaamie Abd Ghani Azmi \\ Syariah and Management, Academy of Islamic Studies, University of Malaya. \\ Email: amieazmi@um.edu.my
}

\begin{abstract}
Previous studies have shown that demographics factors are among the factors that influence the success of an entrepreneur. Therefore, this research aims to examine the relationship between demographic variable that comprises of ages, the length of running a business and business capital towards the achievement of a successful Muslim entrepreneur in Malaysia. Pearson Correlation test is used to identify the relationship between ages, the length of running a business and business capital, whereas ANOVA Test and $\mathbf{T}$ Test is used to used to determine the relationship differences between ages, the length of running a business and business capital towards the achievement of a successful Muslim entrepreneur in Malaysia. This research verified that there is a significant relationship between ages, the length of running a business and business capital towards the achievement of a successful Muslim entrepreneur in Malaysia. However, only age and business capital has a significant effect with the achievement of successful entrepreneur in Malaysia. Therefore, the results of this study demonstrate that demographic factors influence the achievement of successful Muslim entrepreneur in Malaysia.
\end{abstract}

Index Terms-relationship, capital, achievement, successful, Muslim, entrepreneur

\section{INTRODUCTION}

When discussing about the success of an entrepreneur, a lot of researchers will refer to about the role of motivation achievement theory by Mc Clelland (1985), which influences the success of an entrepreneur. This theory is about the tendency of an individual to perform better, in a more efficient and effective manner in any field they ventured into. According to Mc Clelland (1985), an individual's motivation to achieve is closely related to their internal motivation that makes up a person's behavior. This behavior can be shaped and driven to achieve success. In this theory, Mc Clelland (1985) emphasized that those who wants to achieve their goals will display different attributes than those who do

Manuscript received July 3, 2014; revised September 15, 2014. not want to achieve it as much. Among the nature of an individual with the desire to deliver is working diligently, being courageous, having keen interest to the work that is done, taking pleasure to learn from people who can contribute to perfection, setting a goal to succeed, focused attention on the future, does not rely on fate, and most of all, a very responsible person.

Mc Clelland (1985) further explains that in the achievement theory, the desire to achieve success for an entrepreneur is divided into two conditions. The first condition is that the motive for success of an entrepreneur will be satisfied whenever they are successful in the ventured business. These entrepreneur needs rivalry to exist to be successful, where they embrace the challenges and are enthusiastic in facing various obstacles. The second motive is to avoid failure. An entrepreneur may consider failure as an insult and since they have the strength to respond to the failures encountered, they will try to find a way out when confronted with any problem [1].

In general, Mc Clelland's Theory discusses the relationship between behavior, attitude, and personality towards the achievement of an entrepreneur. However, there are also other factors that contribute to the success of an entrepreneur which include age demographic of entrepreneurs and its business profile that covers the length of its business period as well as it business capital [1]. Therefore, this research will focus on the influence of age, the length of a running business and business capital towards the achievement of a successful Muslim entrepreneur in Malaysia.

\section{LITERATURE REVIEW}

\section{A. Characteristics of a Successful Entrepreneur}

The achievement of a successful entrepreneur in this research's context refers to Muslim entrepreneurs who succeed in the entrepreneurial activities in Malaysia. A entrepreneur is considered successful if he has certain attributes such as managing a business for more than five 
years, having regular income, ownership of assets, increased number of employees, growing market size, its business capital expands, as well as increased business profits or increased service provided as a result of their successful businesses.

According to Brockhaus, a business is considered successful if it has been in operation for more than five years. This is because businesses that reached five years have passed the survival stage and have experienced the challenges and obstacles within the business world [2]. A study of 100 companies in the United Kingdom carried out David S. Evans revealed that the older the age of the company is, the stronger they become to survive [3].

The next characteristics of a successful entrepreneur are to have a steady source of income from its business. According to Zaidatol, fixed income basically means that an entrepreneur has a fixed salary every month as a result of the underlying business and its business monthly income will not be reduced, in fact it will record an increase in its annual salary each year. In addition, they also have annual bonuses and would be able to set their wages in accordance with the requirements. According to the research by Zaidatol, $51 \%$ of Bumiputera entrepreneurs in Malaysia do not have fixed income from its underlying business. This is basically due to the fluctuations in their business and that they do not have the skills to handle financial aspects of the company [4].

A further characteristic is the ownership of assets as a result of the business - this is also a way to measure if an entrepreneur is successful or not. According to Suraidi, typical assets owned include vehicles, residential property, investment property as well as shares and stocks. A research by Suraidi against Amanah Ikhtiar Malaysia (AIM) entrepreneurs revealed that almost $80 \%$ of AIM's entrepreneurs own assets as a result of these activities [5].

In addition, an entrepreneur is considered successful if they have personal savings as a result of the business. These savings are for personal and family rather than business needs. Personal needs may include retirement savings, investment to perform the hajj or Umrah or education funds for their children [5]. According to a study done by Suraidi, $70 \%$ of entrepreneurs under the Amanah Ikhtiar Malaysia (AIM) Scheme have savings as a result of business conducted [5].

According to Shalit, an increase in the number of employees is also a measure of an entrepreneur's achievement. This is because the increase in the labor force verified an increased output, capital and the company's ability to grow [6]. The study, conducted by Brian, proved that increase employee has a significant relationship with the business's performance. According to him, business that have employees are more successful than businesses that do not have employees [7].

According to Chea Peou, an entrepreneur's achievement of success can be measured by the development of market size, business capital, increasing business profits, products or services. Chea Peou applied the Cronbach Alpha Reliability Test on the expansion of market size, business capital, increase profit and increase product or service as a tool to measure the achievement of a successful entrepreneur [8]. According to Chea Peou, the Cronbach Alpha test of the market size is a measure of an entrepreneur success. The alpha value for the market size development is 0.905 , increase in its business capital is 0.919, increased profits is at 0.894 and increased sales or service is at 0.894 [8]. This proves that the market size, business capital, increased profit and increased product or services can be used to measure the success of an entrepreneur.

\section{B. The Relationship between the Age, the Length of Running a Business and Business Capital towards the Achievement of a Successful Entrepreneur}

A research by Olson revealed that the background of entrepreneurs and its business influences the growth and success of an entrepreneur [9]. This research will focus on age, the length of running the business and its business capital.

1) The relationship between an entrepreneur's age and their achievement

The age of an entrepreneur is correlated with their achievements. Ma'ruf Redzuan research proved that an entrepreneur's age has a significant relationship with the achievement of women entrepreneurs in the southern Peninsula Malaysia. The majority of entrepreneurs aged 41-60 years old (71\%) are more successful in their businesses as compared to those not within this age range. This is because entrepreneurs aged 41-60 years have faced life's challenges, are more experienced, and are heavily involved with their ventured businesses. All these factors contributed to their success in business in contrast to those under 40 years old [10]. This research is further supported by a study by Alina Zapalska who uncovers that the majority of entrepreneurs who ventured into businesses in Poland are within the astounding age range of 35- 50 years (with a median age of 45). They have at least one to 25 years of experience in management and the business field [11]. This is in contrast to a research done by P-S Sheet, according to PSheet, entrepreneurs in Singapore is in the range of 3140 years old, which is under the age of 40 . This is because their level of confidence is high, they possess a very positive and optimistic attitude to succeed and are eager to achieve success in business [12]. This study supports the theory of "the achievement" which was highlighted by Mc Clelland that behavior and having the attitude to achieve success encourages them to keep moving forward. This group will always try to find a way out when confronted with any problem [13].

H1: There is a difference in the relationship between the entrepreneur's age and the successful achievement of Muslim entrepreneurs in Malaysia

2) The relationship between the length of running a business and an entrepreneur's achievement

According to Gundry \& Welsh, The length of running a business is related with the development rate of a business [14]. This research is supported by a study done 
by Wiklund \& Shepherd which explains that business years contributed to an entrepreneur's performance achievement [15]. However according to Gundry \& Welsh, there is a difference between the length of running a business with entrepreneur's business scale. It affects the performance of small-scale entrepreneurs, but it does not affect large scale businesses [14].

H2: There are differences in the relationship between length of running a business with an entrepreneur's successful achievement in Malaysia.

3) The relationship between business capital and an entrepreneur's achievement

Business capital is the key to developing any business. Normally, an entrepreneur must have sufficient financial resources to carry out its business activities. Without sufficient capital, a business will not grow and there is a possibility that these activities will fail. According to a study by Mannan, business capital has significant differences in entrepreneurs' achievement [16]. Hendrickson \& Psarouthakis further added that most entrepreneurs need business capital and they will use their savings, borrow from family members and friends to start the business [17]. Shahdan research proved that $50.7 \%$ of micro-businesses, $45 \%$ of small and mediumsized businesses and 33\% of large-scale businesses that do not have enough financial capital faced problems in the businesses [18]. This study was supported by Kyambalesa, who revealed that sufficient business capital is needed to purchase office groceries, pay employees' salaries, pay bills, rental of office buildings, office equipment and furniture as well as office daily expenses . Beside that entrepreneurs will face financial problems when they are developing a business. This can be detected by observing the lack of personal savings of entrepreneurs [19]. Based on these studies, there is a significant relationship between the business capital and the achievements of successful entrepreneurs.

H3: There are differences in the relationship between the business capital relationship with an entrepreneur's successful achievement in Malaysia

\section{METHODOLOGY}

A field study was conducted among 206 Muslim entrepreneurs in Malaysia who has successfully run their business for more than five years. The study is also aimed to test the hypothesis of the study. The dependent variable in this study was the achievement of successful entrepreneurs. An entrepreneur is considered successful if he has a number of achievements in his business such as an increase in the workforce, owning fixed assets, net assets and an increase in its paid-up capital. In this study, entrepreneurs' performance is measured from eight items that is answerable in a five point scale. Each scale is to measure the magnitude of the respondents answer with 1 being 'Strongly Disagree' to 5 being 'Strongly Agree'. These items comprises of increased income from the business, owning of assets, growth in savings, the number of workers increases, the business market size expands, its business capital increases, its business profitability escalates, and the sale of products or services increases. The Cronbach alpha value of the eight items is 0.9 . This reflects that the question has a high reliability.

In order to verify the hypothesis, the following tests were performed: Pearson Correlation Test, ANOVA Test as well as the $\mathrm{T}$ Test. Pearson Correlation Test is to determine the relationship between age, length of running a business and business capital towards an entrepreneur's successful achievement, whilst ANOVA Test and T Test was conducted to determine the different age group, length of running a business and business capital towards an entrepreneur's successful achievement in Malaysia.

\section{RESULT}

This study consisted of 206 respondents, with the majority being men $(70 \%)$ and remaining $30 \%$ are women. $42 \%$ of the respondents were aged between 41 50 years, and $83 \%$ of these entrepreneurs are married. $44 \%$ of them have at least a Degree, with $36 \%$ of them having a Degree in Islamic studies. In addition, most of these respondents have been involved with their business for more than five years. As much as $30 \%$ of these entrepreneurs have more than one business, and $30 \%$ is engaged in the business services sector. A majority of the entrepreneurs $(82 \%)$ founded their own business, while $13 \%$ inherited their family business. More than half of them $(59 \%)$ started their business with a capital of less than RM100, 000 and 21\% started their business between RM101,000 to RM500,000. As much as 44\% of these entrepreneurs used their own savings as their business capital while $20 \%$ seeked capital from their family. More than half of these entrepreneurs $(54 \%)$ located their business in town while $24 \%$ runs their business in small town. $62 \%$ of the entrepreneurs has less than 100 employees and $57 \%$ have an average monthly profit below RM100, 000.

Next is the result of the relationship between age, length of running a business and the business capital towards an entrepreneur's successful achievement. The results of Pearson correlation analysis showed that age (r $=176 * *, p<012)$, length of running a business $(r=225$, $\mathrm{p}<001)$, and business capital $(\mathrm{r}=227 * *, \mathrm{p}<001)$ has a significant relationship with the achievement factors of entrepreneurs. Table I reflects the Pearson correlation analysis of the hypotheses with regards to an entrepreneur's successful achievement.

TABLE I. PEARSON CORRELATION ANALYSIS ON THE VARIABLE TOWARDS AN ENTREPRENEUR'S SUCCESSFUL ACHIEVEMENT

\begin{tabular}{|c|c|c|}
\hline Variable & $(\mathrm{r})$ & Significant \\
\hline Age & $.176 * *$ & .012 \\
\hline $\begin{array}{c}\text { Length of running a } \\
\text { business }\end{array}$ & $.225 * *$ & .001 \\
\hline Business Capital & $.227 * *$ & .001 \\
\hline
\end{tabular}


The result of the study that looks into the differences in age, years in business and the business capital towards an entrepreneur's successful achievement is as follows :-

H1: There are differences in the relationship between the age of an entrepreneur and the successful achievement of Muslim entrepreneurs in Malaysia.

ANOVA Test Results for age level and entrepreneur's successful achievement is as displayed below:

TABLE II. THE DISTRIBUTION OF THE ENTREPRENEUR'S ACHIEVEMENT ACCORDING TO AGE GROUP

\begin{tabular}{|c|c|c|c|}
\hline Age & $\begin{array}{c}\text { Number } \\
(\mathbf{n})\end{array}$ & $\begin{array}{c}\text { Minimum } \\
\text { Score }\end{array}$ & $\begin{array}{c}\text { Standard } \\
\text { deviation }\end{array}$ \\
\hline Under 30 years & 29 & 3.7328 & .61757 \\
\hline 31-40 Years & 36 & 3.7847 & .65507 \\
\hline 41-50 Years & 87 & 4.0934 & .61095 \\
\hline 51-60 Years & 41 & 3.8933 & .49573 \\
\hline 61 Years \& above & 13 & 4.2404 & .59174 \\
\hline Total & 206 & 3.9581 & .61361 \\
\hline
\end{tabular}

Based on the table below, there is a significant difference in the minimum score of an entrepreneur's achievement with the age of successful entrepreneurs in Malaysia. $(\mathrm{F}(2,203)=(3.746 ; \mathrm{P}<0.05)$.

TABLE III. ANOVA TEST - ENTREPRENEUR'S ACHIEVEMENT ACCORDING TO AGE

\begin{tabular}{|c|c|c|c|c|c|}
\hline Age & $\begin{array}{c}\text { The } \\
\text { power } \\
\text { of two }\end{array}$ & $\begin{array}{c}\text { Degrees } \\
\text { of } \\
\text { freedom }\end{array}$ & $\begin{array}{c}\text { Min } \\
\text { power } \\
\text { of } \\
\text { two }\end{array}$ & $\begin{array}{c}\text { Value } \\
\mathrm{F}\end{array}$ & Significance \\
\hline $\begin{array}{c}\text { Between } \\
\text { groups }\end{array}$ & 5.355 & 2 & 1.339 & 3.746 & .005 \\
\hline $\begin{array}{c}\text { In the } \\
\text { group }\end{array}$ & 71.831 & 203 & .357 & & \\
\hline Total & 77.186 & 205 & & & \\
\hline
\end{tabular}

TABLE IV. Post Hoc TuRKey ENTREPRENEUR's ACHIEVEMENT BASED ON AGE

\begin{tabular}{|c|c|c|c|}
\hline Age & $\begin{array}{c}\text { The minimum } \\
\text { difference }\end{array}$ & $\begin{array}{c}\text { Default } \\
\text { Error }\end{array}$ & Significance \\
\hline $\begin{array}{c}\text { Under 30 years 31-40 } \\
\text { years }\end{array}$ & -.05196 & .14916 & .997 \\
\hline $\begin{array}{c}31-40 \text { Years 41-50 } \\
\text { years }\end{array}$ & -.30867 & .11847 & .073 \\
\hline $\begin{array}{c}41-50 \text { Years 51-60 } \\
\text { years }\end{array}$ & .20010 & .11324 & .396 \\
\hline $\begin{array}{c}51-60 \text { Years 61 years } \\
\text { and above }\end{array}$ & -.34709 & .19028 & .363 \\
\hline $\begin{array}{c}\text { 61 Years and above } \\
\text { under 30 years }\end{array}$ & .50763 & .19953 & .085 \\
\hline
\end{tabular}

Based on the table above, an entrepreneur aged 61 years and above have the highest minimum score which is $(\mathrm{M}=4.2404, \mathrm{SD}=.59174)$ as compared to entrepreneurs aged 41-50 years $(\mathrm{M}=4.0934, \mathrm{SD}=.61095)$, entrepreneurs aged 51 to 60 years $(\mathrm{M}=3.8933, \quad \mathrm{SD}=.49573)$, entrepreneurs aged 31 to 40 years $(M=3.7847$, $\mathrm{SD}=.65507)$ and entrepreneurs under the age of 30
$(\mathrm{M}=3.7328, \mathrm{SD}=.61757)$. However, the mean score for all Muslim entrepreneurs do not differ significantly. Although the ANOVA results are statistically significant, the actual difference between the mean score is medium. The effect size used using Eta squared is 0:07 [20]. However, these hypotheses are accepted. This study supports the research done by Ma'arof Redzuan [10] and Alina Zapalska [11] which revealed that entrepreneurs aged 40-60 years are more successful in the ventured business as opposed to entrepreneurs under the age of 40 . This is because entrepreneurs aged 40-60 years have faced the challenges of life, they are more experienced, and are heavily involved with their business. Therefore, they are more successful in their businesses compared to those under the age of 40. This study is further supported by Alina Zapalska's research, which proved that entrepreneurs age 35-50 years (median age 45) are more successful in their business because they have more than one year to 25 years of experience in management as well as business[11].

H1: There are distinct differences between the length of running a business with an entrepreneur's successful achievement in Malaysia

$\mathrm{T}$ test was used to determine the differences of entrepreneurs' achievement success for those who have been operating their business within 5 to 10 years and those who have been in business for more than 10 years. The analysis revealed that entrepreneurs who have been in operation for more than 10 years have a higher minimum achievement scores compared to the entrepreneurs who has only been running their businesses around 5 to 10 years $(M=4.1102 ; \mathrm{SD}=.51336$ for entrepreneurs who has been in business 10 years and above, $\mathrm{M}=3.8330 ; \mathrm{SD}=.66157$ for entrepreneurs who run businesses from 5 to 10 years). The results are as tabulated in Table $\mathrm{V}$ below.

TABLE V. T TEST : THE RELATIONSHIP BETWEEN LENGTH OF RUNNING A BUSINESS AND ENTREPRENEUR'S ACHIEVEMENT

\begin{tabular}{|c|c|c|c|c|c|}
\hline $\begin{array}{c}\text { Length of } \\
\text { running a } \\
\text { business }\end{array}$ & No. & Min & $\begin{array}{c}\text { Standard } \\
\text { deviation }\end{array}$ & $\begin{array}{c}\text { T } \\
\text { Value }\end{array}$ & Significant \\
\hline $\begin{array}{c}5-10 \\
\text { years }\end{array}$ & 113 & 3.8330 & .66157 & -3.304 & .022 \\
\hline $\begin{array}{c}\text { More than } \\
\text { 10 years }\end{array}$ & 93 & 4.1102 & .51336 & -3.385 & \\
\hline
\end{tabular}

The $\mathrm{T}$ test analysis revealed that the $\mathrm{p}$ value is 0.22 and is less than the alpha value used (0.05). Therefore, the hypothesis that states there is a significant difference with the entrepreneurs' achievement and the length of running a business is not accepted. This study supports the research by Gundry \& Welsh, who observed that the length of running depends on the type of business. According to Gundry \& Welsh, there are differences in a small-scale business capital, but there is no difference to the large-scale businesses [14]. 
H3: There are distinct differences in the relationship between the business capital and an entrepreneur's successful achievement in Malaysia

ANOVA test results on business capital and entrepreneurs' successful achievements are shown in as below:

TABLE VI. THE DISTRIBUTION OF THE ENTREPRENEUR'S ACHIEVEMENT ACCORDING TO BUSINESS CAPITAL

\begin{tabular}{|c|c|c|c|}
\hline Business Capital & Number & $\begin{array}{c}\text { Minimum } \\
\text { Score }\end{array}$ & $\begin{array}{c}\text { Standard } \\
\text { deviation }\end{array}$ \\
\hline Under RM100,000 & 118 & 3.8708 & .61214 \\
\hline RM101,000-RM500,000 & 42 & 3.8988 & .55781 \\
\hline RM501,000 to the top & 46 & 4.2364 & .59584 \\
\hline Total & 206 & 3.9581 & .61361 \\
\hline
\end{tabular}

Based on the table below, there is a significant difference in the minimum achievement score of entrepreneurs with business capital $(\mathrm{F}(2,203)=(6.448$; $\mathrm{P}<0.002)$.

TABLE VII. ANOVA TEST ENTREPRENEUR'S ACHIEVEMENT ACCORDING TO BUSINESS CAPITAL

\begin{tabular}{|c|c|c|c|c|c|}
\hline $\begin{array}{c}\text { Business } \\
\text { capital }\end{array}$ & $\begin{array}{c}\text { The } \\
\text { power } \\
\text { of two }\end{array}$ & $\begin{array}{c}\text { Degrees } \\
\text { of } \\
\text { freedom }\end{array}$ & $\begin{array}{c}\text { Min of } \\
\text { the } \\
\text { power } \\
\text { two }\end{array}$ & $\begin{array}{c}\text { Value } \\
\mathrm{F}\end{array}$ & Significance \\
\hline $\begin{array}{c}\text { Between } \\
\text { groups }\end{array}$ & 4.611 & 2 & 2.305 & 6.448 & .002 \\
\hline $\begin{array}{c}\text { In the } \\
\text { group }\end{array}$ & 72.575 & 203 & .358 & & \\
\hline Total & 77.186 & 205 & & & \\
\hline
\end{tabular}

TABLE VIII. POST HOC TURKEY ENTREPRENEUR'S ACHIEVEMENT BASED ON BUSINESS CAPITAL

\begin{tabular}{|c|c|c|c|}
\hline Business Capital & $\begin{array}{c}\text { The Minimum } \\
\text { Distinction }\end{array}$ & $\begin{array}{c}\text { Default } \\
\text { Error }\end{array}$ & Significance \\
\hline $\begin{array}{c}\text { Under RM100,000 } \\
\text { RM101,000-RM500,000 }\end{array}$ & -.02805 & .10743 & .963 \\
\hline $\begin{array}{c}\text { RM101,000-RM500,000 } \\
\text { RM501,000 to the top }\end{array}$ & -.33760 & .12761 & .024 \\
\hline $\begin{array}{c}\text { RM501,000 to the top } \\
\text { Under RM100,000 }\end{array}$ & .36565 & .10393 & .002 \\
\hline
\end{tabular}

Based on the table above, entrepreneurs with business capital of RM500,000 and above obtained the highest mean score $(\mathrm{M}=4.2364, \mathrm{SD}=.59584)$ as compared to entrepreneurs with capital of RM101,000 to RM500,000 $(\mathrm{M}=3.8988, \mathrm{SD}=.55781)$ and entrepreneurs with capital of RM100,000 (M=3.8708, SD=.61214).However, the mean scores for Muslim entrepreneurs who started with a capital of RM100,000 and entrepreneurs who have a business capital of RM101,000 to RM500,000 did not differ significantly. Although, ANOVA results were statistically significant, the actual difference in the mean scores between groups is medium. The effect size used for Eta squared is 0.06 [20]. This study is supported by the research by Mannan [16], Hendrickson [17], Kyambalesa [19] and Shadan [18] who found that the larger the business capital is owned by an entrepreneur, the more promising it is for them to be successful in their business. This is because business capital is the key to developing a business- without sufficient capital, the business will not grow and is doomed for failure.

\section{CONCLUSION}

As a conclusion, the hypothesis tests carried out proved that there are significant relationships between age, the length of running a business and business capital towards an entrepreneurs' successful achievement in Malaysia. The results proved the level of age, specifically 40 years and above, affects the achievement of successful entrepreneurs in Malaysia, whereby the older an entrepreneur is, the higher their achievements is in the business. This is because entrepreneurs aged 40-60 years have faced life challenges, are more experienced, and are heavily involved with their business. Apart from the age of an entrepreneur, business capital is also one of the factors that influenced Muslim entrepreneurs' successful achievement in Malaysia. A steady and sufficient capital will indicate a better chance for success. Business capital is needed to complete the business cycle, to buy groceries, pay salaries, pay bills, pay office rent, purchase equipment and furniture as well as daily office expenses. Entrepreneurs will face financial problems if there is insufficient business capital and this would interfere with the development of the business. However, the results of this research proved that the length of running a business is related towards the achievements of successful entrepreneurs in Malaysia but that there is no difference with the time taken and entrepreneurs' achievement.

\section{REFERENCES}

[1] D. C. Mc Clelland, Human Motivation, New York: Cambridge University Press, 1985, pp. 226.

[2] R. H. Brockhaus, "Risk-taking propensity of entrepreneurs," Academy of Management Journal, vol. 23, no. 3, pp. 509-520, 1990.

[3] S. D. Evans, "The relationship between firm growth, size and age: Estimates for 100 manufacturing industries," The Journal of Industrial Economics, vol. XXXV, pp. 567-580, June 1987.

[4] L. P. Z. Akmaliah and E. Habibah, "The entrepreneurial expertise of the Bumiputera industrialist: A Case Study," UPM: Pertanika Journal Science and Humanity, vol. 12, no. 1, pp. 61-70, 2004.

[5] S. Suraidi, " The relationship between the desire for success, locus of control, risk-taking and social networking together with the successful of the entrepreneur's Amanah Ikhtiar Malaysia in Kelantan. Master dissertation, Selangor: Universiti Putra Malaysia, 2005.

[6] S. S. Shalit and U. Shankar, "The measurement of firm size," The Review of Economics and Statistic, vol. 6, pp. 11-40, 1977.

[7] H. Brian, Business Success: Factors Leading to Surviving and Closing Successfully, Washington DC: Economic Planning and Coordination, Center for Economic Studies, 2002.

[8] C. Peou, "Relationship between entrepreneur value, firm financing, firm management, market practices and growth performance of small and medium enterprises in Cambodia," $\mathrm{PhD}$ dissertation, Kedah: North University Malaysia, 2009.

[9] P. D. Olson, "The impact of the family and the business on family business sustainability," Journal of Business Venturing, vol. 18, pp. 639-666, 2003. 
[10] R. Ma'arof, A. R. A. Razak, and M. N. N. Aina,"The establishment of individual expertise among women entrepreneurs on small scale industries.", Academia, 2012, vol. 82, no. 1, pp. 5764.

[11] Z. Alina, "A profile of women entrepreneurs and enterprise in Poland," Journal of Small Business Management, vol. 35, no. 4, pp. 76, Oct 1997.

[12] P. S. Seet and A. N. Hazlina, "Singapore female Entrepreneurs-are they different?" International Journal Entrepreneurship and Small Business, vol. 5, pp. 3, 2008.

[13] D. C. Mc Clelland, The Achieving Society, New York: Free Press, 1961.

[14] L. K. Gundry and H. P. Welsch, "The ambitious entrepreneur: High growth strategies of women owned enterprises," Journal of Business Venturing, vol. 16, pp. 453-470, 2001.

[15] J. Wiklund and D. Shepherd, "Entrepreneurial orientation and small business performance," A Configurational Approach, Journal of Business Venturing, vol. 20, pp. 71-79, 2005.

[16] A. M. Mannan, Growth and Development of Small Enterprise: Case of Bangladesh, UK: Ashgate Publishing Co, 1993, pp. 52

[17] U. L. Hendrickson and J. Psaroutthakis, Managing the Growing Firm, USA: Prentice-Hall, Inc, 1992, pp. 73.

[18] F. Shahadan, M. Berma, M. R. Zin, and Z. Mahbar, "The growth constrain of small and medium enterprise in Malaysia: Myth or reality?" in Proc. the International Conference on Small and Medium Scale Enterprise, 1988, pp. 277-30.

[19] H. Kyambalesa, Successful in Managing a Small Business, UK: Ashgate Publishing Lt, 1994, pp. 93.

[20] J. Cohen, Applied Multiple Regression/Correlation Analysis for the Behavioral Sciences, New York: Erlbaum, 1988, pp. 87.

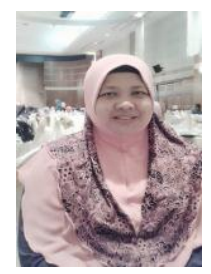

Yazilmiwati Yaacob born on Feb 8, 1975 in Malaysia. Her first degree is in Dakwah and Human development from Academy of Islamic Studies, University of Malaya Kuala Lumpur Malaysia, Her Master is in Dakwah and leadership from Academy of Islamic Studies, National University, Selangor Malaysia. Now she pursuing her $\mathrm{PhD}$ at Department of Syariah and Management, University of Malaya
Kuala Lumpur. Her research interest is in Islamic entrepreneurship.

She is a senior lecturer at Sunway University Malaysia for twelve years. She frequently presenting a paper at local and international conference. Her research interest is in Islamic entrepreneurship.

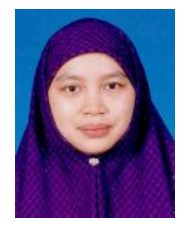

Ilhaamie Abdul Ghani Azmi, Associate Professor at Department of Syariah and Management, Academy of Islamic Studies, University Malaya, Kuala Lumpur. She obtained her $\mathrm{PhD}$ at USM, MBA from UKM and BBA, UIAM. Her current research interests are entrepreneurship, human resource management, service quality and Islamic management. To date, she has authored two books, co-editored two books, published 24 articles and 54 papers. Two of her papers have won best paper award at the international conferences. She also has been awarded with 13 research grants whereby she had accepted 11 of them due to unforeseen circumstances. She also was awarded as Fellow Researcher at University of Wollongong, Australia and Universiti Malaysia Kelantan in 2013. In 2003 and 2009 respectively, she was bestowed with Excellence Awards and a certificate of Excellence from University Malaya in 2010. Due to her passion in research, she is registered in Global Agency Research and International Association of Computer Science and Information Technology as a member. 